\title{
BM] Global Health World Committee on Tourism Ethics (WCTE) recommendation on COVID-19 certificates for international travel
}

\author{
Hiroaki Matsuura
}

To cite: Matsuura H. World Committee on Tourism Ethics (WCTE) recommendation on COVID-19 certificates for international travel. BMJ Global Health 2021;6:e006651. doi:10.1136/ bmjgh-2021-006651

Handling editor Seye Abimbola

Received 17 June 2021

Accepted 21 June 2021

\section{Check for updates}

(c) Author(s) (or their employer(s)) 2021. Re-use permitted under CC BY-NC. No commercial re-use. See rights and permissions. Published by BMJ.

Faculty of Tourism, Media, and Cultural Studies, Shoin University, Atsugi, Japan

Correspondence to Professor Hiroaki Matsuura; hiroaki.matsuura@shoin-u.ac.jp
Restarting tourism is a priority for many countries, especially those whose economies rely heavily on revenues generated by international tourism. ${ }^{1}$ As the pandemic is still ongoing, vaccine certificates are, so far, the only way to revive international travel and other activities. However, there remain considerable ethical and practical challenges facing their implementation. ${ }^{2}$

WHO is reluctant to endorse COVID-19 certificates. Following the most recent meeting of the International Health Regulations Emergency Committee regarding the COVID-19 pandemic, the committee explicitly stated its opposition to international travellers being required to provide proof of vaccination. ${ }^{3}$ The committee urged member states to 'acknowledge the potential for requiring such certificates' may 'deepen inequities and promote differential freedom of movement." ${ }^{3}$

However, as summer tourist season is approaching in the Northern Hemisphere, there is an urgent need to restart tourism in order to mitigate further harm to the tourism sector, which has been devastated by the pandemic. On 4 May, the G20 Tourism Ministers met and expressed support for using vaccine certificates to boost travel and tourism, stressing that such resumptions are crucial for global economic recovery. ${ }^{4}$ Israel and the State of New York have already introduced vaccine certificates primarily for domestic purposes (but also for international travel). More recently, the European Parliament and member states reached a provisional agreement on the Digital COVID-19 Certificate, confirming that the certificate will go live on 1 July. ${ }^{5}$ Many other vaccine certificate programmes are in development. As of 3 June, 36 airline companies have already started trialling the International Air Transport Association Digital Travel Pass. ${ }^{6}$

Regardless of the WHO's position on COVID-19 certificates, such certificates are
Summary box

- WHO has not yet endorsed the COVID-19 certificates. However, the European Union, nation states and the airline companies recently introduced, or will soon introduce COVID-19 certificates to open their borders to vaccinated visitors.

- The World Committee on Tourism Ethics, an independent and impartial body under the aegis of the World Tourism Organization, issued a Recommendation, requesting governments and other entities to implement COVID-19 certificates for international travel in free, universally available and non-discriminatory manner.

- The recommendation also limits its use and time as well as the provision of vaccines and certificates as a part of international holiday packages.

already required to enter several countries, and other countries are considering their introduction. To resolve this disconnect, on 7 May, the World Committee on Tourism Ethics, an independent and impartial body of the General Assembly of the World Tourism Organization, met and issued a recommendation for the ethical implementation of COVID-19 certificates for international travel. ${ }^{7}$ The recommendation does not urge the use of COVID-19 certificates but rather sets essential conditions for implementing COVID-19 certification programmes ethically. Seven independent conditions are recommended based on the Global Code of Ethics for Tourism and the Framework Convention on Tourism Ethics.

The first item defines the COVID-19 certificate as a unique document taking one or more of the following forms: a vaccination certificate (proof of vaccine-acquired immunity), a COVID-free certificate (proof of noninfection) or a certificate of recovery (proof of infection-acquired immunity).

Recently, public debate has been heated regarding the greater ethicality of vaccine certificates compared with certificates of 
recovery for the following two reasons. First, vaccineacquired immunity is more reliable in terms of effectiveness and duration compared with infection-acquired immunity. Second, vaccine certificates would create an incentive to get vaccinated while immunity certificates would create a misguided incentive to intentionally expose oneself to acquire immunity. The recommendation is primarily a response to the recent move towards requiring vaccine certificates, but it is also relevant for other types of certificates, namely COVID-free certificates or certificates of recovery.

The second item restricts the use of COVID-19 certificates to international travel. Some advocate for requiring vaccine certificates to access a wide range of public and private spaces domestically. However, such a requirement could restrict the civil liberties and daily activities of those who are not vaccinated, exacerbating existing societal and health inequalities. Requiring vaccine certificates for international travel is less harmful because many countries have already closed their borders and it is unlikely that travellers with no certificate can enter such countries until the pandemic is over at the global level. The sixth item further requires governments to work towards reducing the accessibility gap to COVID-19 certificates by ensuring the population's wide access to free vaccines, affordable tests and free certificates. Note that the second item does not intend to limit the use of COVID-19 certificates for domestic purposes; rather, it considers the ethicality of COVID-19 certificates for international travel separately from the ethicality of certificates for domestic use.

The third item establishes that COVID-19 certificates for international travel should cease to be required as soon as the WHO declares the end of the Public Health Emergency of International Concern. Certificate requirements should not bar the entry of unvaccinated visitors once the external threat posed by COVID-19 is reasonably low.

The fourth item requires the certificate to be available both in digital and paper formats. As many vulnerable and disadvantage people do not have smartphones or access to stable internet connections, they are more likely to be excluded from the COVID-19 certificate system if the certificate is only available digitally. This is particularly the case in low-income and middle-income countries where information and communication infrastructure is weak.

The fifth item ensures data protection and the privacy of the COVID-19 certificate, which contains personal medical information. Together with item 6 , the fifth item requires government and other entities to ensure data protection, privacy and that people can acquire and maintain the certificates for free. Free certificates with vaccines and affordable tests are helpful not only in ensuring equality of access to COVID-19 certificates but also in preventing fake certificates since high costs incentivise a market for fake certificates. It also requires that personal medical information obtained for the COVID-19 certificate not be used for purposes other than entry into a country.

Finally, the last item explicitly cautions countries against pursuing vaccination tourism, stating that 'vaccines should not form part of vaccination holiday packages and must remain a global public good.' Those with the financial means to travel and get vaccinated would benefit from vaccine tourism, but the attendant depletion of vaccines for locals creates ethical problems as the majority of the world's population waits for access to vaccines.

The recommendation aims to enable COVID-19 certificates to pave the way for safer and free international travel and restore confidence in tourism while considering ethical and human rights concerns from the viewpoint of tourism ethics. The technological, sanitary and legal matters related to COVID-19 certificates do not fall under the remit of this Committee. For this reason, this list is neither sufficient nor comprehensive to implement the use of COVID-19 certificates. Feedback from the legal, medical and scientific communities and further efforts for global coordination and the standardisation of the certification system are absolutely necessary to fairly and effectively implement COVID-19 certificates for international travel at the global level.

Twitter Hiroaki Matsuura @muppy_e

Contributors HM is solely responsible for all process.

Funding The authors have not declared a specific grant for this research from any funding agency in the public, commercial or not-for-profit sectors.

Competing interests None declared.

Patient consent for publication Not required.

Provenance and peer review Not commissioned; internally peer reviewed.

Data availability statement No data are used in this manuscript.

Open access This is an open access article distributed in accordance with the Creative Commons Attribution Non Commercial (CC BY-NC 4.0) license, which permits others to distribute, remix, adapt, build upon this work non-commercially, and license their derivative works on different terms, provided the original work is properly cited, appropriate credit is given, any changes made indicated, and the use is non-commercial. See: http://creativecommons.org/licenses/by-nc/4.0/.

\section{ORCID iD}

Hiroaki Matsuura http://orcid.org/0000-0003-2332-1176

\section{REFERENCES}

1 UNWTO. Global guidelines to restart tourism, 2020. Madrid: UNWTO. Available: https://webunwto.s3.eu-west-1.amazonaws.com/s3fspublic/2020-05/UNWTO-Global-Guidelines-to-Restart-Tourism.pdf

2 Osama T, Razai MS, Majeed A. Covid-19 vaccine passports: access, equity, and ethics. BMJ 2021;373:n861.

3 WHO. Statement on the seventh meeting of the International health regulations emergency Committee regarding the coronavirus disease pandemic, 2021. Geneva: WHO. Available: https://www.who.int/ news/item/19-04-2021-statement-on-the-seventh-meeting-of-theinternational-health-regulations-(2005)-emergency-committeeregarding-the-coronavirus-disease-(covid-19)-pandemic

4 G20. Tourism Ministerial meeting, 2021. Available: https://www.g20. org/wp-content/uploads/2021/05/G20-Tourism-Ministerial-MeetingMedia-Handbook-ENG.pdf

5 Europain Comission. EU Digital COVID Certificate: European Parliament and Council Reach Agreement on Commission Proposal Brussels: Europain Comission,, 2021. Available: https://ec.europa.eu/ commission/presscorner/detail/en/IP_21_2593

6 IATA. IATA travel pass initiative havana, 2021. Available: https://www. iata.org/en/programs/passenger/travel-pass/

7 WCTE. Recommendation on COVID-19 certificates for international travel, 2021. Available: https://webunwto.s3.eu-west-1.amazonaws. com/s3fs-public/2021-05/WCTE_Rec_COVID19Certificate_Final_0. pdf?rc8dui4ZzJlohERId7aozQH3omxWj6Dz= 